\title{
Sampling the $\mathrm{C}$ of the deep Earth: In situ C-O-Sr isotopes of kimberlitic carbonates worldwide
}

\author{
MontgarRi CASTILlO-OLIVER ${ }^{1}$, ANDREA GIULIANI ${ }^{2}$,
} WILLIAM L. GRIFFIN ${ }^{1}$, SUZANNE Y. O'REILLY ${ }^{1}$, RUSSELL N. DRYSDALE ${ }^{3}$, XIAN-HUA LI ${ }^{4}$

${ }^{1}$ [ARC Centre of Excellence for Core to Crust Fluid Systems (CCFS) and GEMOC, Macquarie University, Australia; montgarri.castillo-oliver@mq.edu.au*, bill.griffin@mq.edu.au, sueoreilly@mq.edu.au]

${ }^{2}$ [Institute of Geochemistry and Petrology, ETH Zürich, Switzerland; andrea.giuliani@erdw.ethz.ch]

${ }^{3}[$ School of Geography, The University of Melbourne, Australia; rnd@unimelb.edu.au]

${ }^{4}$ [State Key Laboratory of Lithospheric Evolution, Institute of Geology and Geophysics, Chinese Academy of Sciences, China; 1 ixh@gig.ac.cn]

The deep source of the kimberlite parental melts $(>250$ $\mathrm{km}$ ), combined with their high $\mathrm{CO}_{2}$ contents, turn them into unique probes of $\mathrm{C}$ of the lithospheric mantle. Recent in situ $\mathrm{C}-\mathrm{O}-\mathrm{Sr}$ isotope work in kimberlite carbonates has shown that, despite carbonate petrogenesis can be very complex and multiple sources are involved in their formation, it is possible to identify primary pristine carbonates in kimberlites and thus elucidate the $\mathrm{C}-\mathrm{O}$ isotopic compostion of their parental melts [1]. Following the same multi-technique approach, carbonates of fresh hypabyssal kimberlites worldwide have been studied, including petrographic examination, major-, minor-element and both bulk carbonate and in situ $\mathrm{C}-\mathrm{O}-\mathrm{Sr}$ isotope analysis.

Our studies highlight again the petrological diversity of kimberlitic carbonates and in situ isotope systematics yield a wide $\delta^{18} \mathrm{O}$ range (+6 to $+28 \%$ ), depending on their source (i.e., primary, deuteric, secondary). In contrast, the $\mathrm{C}$ isotope anaylsis yield a significantly more restricted range $\left(\delta^{13} \mathrm{C}=-4\right.$ to $-6 \%$ in $>92 \%$ of the samples), regardless of their origin. The bulk-carbonate $\mathrm{O}$ isotope analysis are misleading, since they are a mixture of the different generations of carbonates, whereas bulk-carbonate $\mathrm{C}$ isotopes are consistent with in situ measurements, indicating that late processes (i.e., crustal assimilation, degassing, deuteric alteration, weathering) do not significantly modify the $\delta^{13} \mathrm{C}$ composition of the kimberlite parental melts. The finding that pristine magmatic carbonates, unaffected by other processes, carry typical mantle C-O isotopic signatures $\left(\delta^{13} \mathrm{C} \sim-4\right.$ to $-6 \%$ and $\delta^{18} \mathrm{O} \sim$ 6 to $9 \%$ ) suggests that recycled crustal material has contributed little if anything to the source of kimberlites. No significant variations $\delta^{13} \mathrm{C}$ are seen through time and space.

[1] Castillo-Oliver et al. (2020), CMP 